\title{
Allelopathic Potential of Orsellinic Acid Derivatives
}

\author{
Marize Terezinha Lopes Pereira Peres ${ }^{1 *}$, Ana Maria Mapeli ${ }^{1}$, Odival Faccenda ${ }^{2}$, Alcir \\ Teixeira Gomes ${ }^{3}$ and Neli Kika Honda ${ }^{3}$ \\ ${ }^{I}$ Departamento de Hidráulica e Transportes; Universidade Federal de Mato Grosso do Sul; Campo Grande - MS - \\ Brasil. ${ }^{2}$ Departamento de Computação e Ciências da Informação; Universidade Estadual de Mato Grosso do Sul; \\ Dourados - MS - Brasil. ${ }^{3}$ Departamento de Química; Universidade Federal de Mato Grosso do Sul; Campo Grande \\ - MS - Brasil.
}

\begin{abstract}
Environmental degradation caused by the excessive use of pesticides has motivated studies aimed at the discovery of new formulations for pest control. The bioassays carried out under laboratory conditions for the present study involved the germination and seedling growth of Lactuca sativa cv. Grand Rapids and Allium cepa cv. Baia Periforme treated with lecanoric acid or one of seven esters obtained from the alcoholysis of the acid. Each substance was tested at concentrations of $10^{-3}, 10^{-5}, 10^{-7} \mathrm{M}$, and $10^{-9} \mathrm{M}$. The results revealed that, except for lecanoric acid and methyl orsellinate, all other compounds exhibited significant differences in their action when compared with the controls. Also, A. cepa was more sensitive to the compounds assayed, at the concentrations tested. Nearly all the esters exhibited significant effects, a feature that could makes them promising for the development of new natural herbicides.
\end{abstract}

Key words: allelopathy, germination, growth, Lactuca sativa, Allium cepa, orsellinates

\section{INTRODUCTION}

The use of chemicals to fight the pests, though leading to higher productivity in a shorter time, has to be conducted in a careful manner, given the range of risks posed by this practice - including contamination of aquifers by infiltration and pesticide leakage; development of insect and weed resistance brought about by biochemical, morphological, and physiological changes; environmental degradation; and diseases caused or triggered by exposure to these products (Coutinho, 1996 in Silva Cruz et al., (2000).

Plants produce secondary metabolites, many of which influence growth and distribution of other plants. Such metabolites have been the object of studies, as part of the search for natural herbicides and for a better understanding of their effects on cultivated areas, taking into account not only ecological aspects, but also economical ones (Einhellig, 1995).

Random screening is a valuable practice that can provide guidance in the search for new compounds with herbicidal activity (Cobb, 1992). The study of the germinative behavior of plant species submitted to the action of allelochemicals involves the use of bioassays, making it possible to evaluate the allelopathic potential of the species under investigation and to follow up their biological response during the stages of extraction,

\footnotetext{
* Author for correspondence: marizeperes@ hotmail.com
} 
fractioning, purification, and identification (Peres et al., 1998).

Substances such as alkaloids, anthraquinones, flavonoids, terpenes - monoterpenes, sesquiterpenes and triterpenes; quinones, coumarins, benzoic acid derivatives among others, are examples of allelochemicals agent isolated from several plant species. Many secondary compounds of plants, microorganisms and lichens are known to be toxic to insect, microbes and other organisms. Many of these compounds have been used successfully, either in their natural or a modified form, as inseticides, fungicides and herbicides (Duke and Abbas, 1995). Phenolic substances are included in this group and an example is the herbicide "Letharal" - phytotoxic fraction of Lethariella canariensis. This fraction is a mixture of twelve phenolic substances and the most part of them are substituted monophenols (Marante et al., 2003).

Orsellinic and $\beta$-methyl orsellinic acids and 4-Omethyl derivatives exhibit growth inhibitory activity on lettuce seedling (Nishitoba and Nishimura, 1987). Derivatives from the phenolic substances obtained through the structural modification of natural products, wereevaluated as antimicrobial, allelopathic and antitumoral agents. Among these compounds, orsellinates were prepared through alcoholysis reactions of lecanoric acid - the main constituent of the lichen Parmotrema tinctorum (Nyl) Hale. The homologous series of methyl orsellinate - pentyl orsellinate and compounds with ramified chains iso-propyl, sec-butyl and terc-butyl orsellinates showed a potential activity against Cladosporium sphaerospermum (Gomes et al., 2002). These compounds were tested also against Gram-positive and Gram-negative bacteria. Staphylococcus aureus, Xanthomonas campestris var. vesicatoria and Ralstonia solanacearum were most sensitive to $n$-propyl orsellinate, $n$-pentyl orsellinate and $n$ hexyl orsellinate (Gomes et al., 2003).

The purpose of the present study was to evaluate, under laboratory conditions, the allelopathic potential of lecanoric acid and orsellinates on the germination and seedling growth of Lactuca sativa cv. Grand Rapids (Asteraceae, Dicotyledoneae) and Allium cepa cv. Baia Periforme (Liliaceae, Monocotyledoneae). Each of the eight substances was assayed at the concentrations of $10^{-3}, 10^{-5}, 10^{-}$ ${ }^{7}$, and $10^{-9} \mathrm{M}$, in order to gather data that could contribute to the definition of criteria for the production of natural pesticides.

\section{MATERIALS AND METHODS}

\section{Lichen material}

Parmotrema tinctorum (Nyl.) Hale (Parmeliaceae) was collected in March 1999 in the municipality of Aquidauana, Mato Grosso do Sul, Brazil, and was identified by Dr. Mariana Fleig. A voucher specimen has been deposited (no. 0488) at the Herbarium of the Chemistry Department of Universidade Federal de Mato Grosso do Sul at Campo Grande.

Extraction and isolation. Preparation of lecanoric acid (1): The dry lichen material (65.5 g) was powdered and then Soxhlet-extracted with chloroform and acetone. The acetone extract was evaporated in vacuo and the residue was dissolved with ethyl ether and 5\% sodium bicarbonate. Upon treatment of the aqueous extract with $0.1-\mathrm{N}$ sulfuric acid, lecanoric acid $(9.25 \mathrm{~g})$ was precipitated and dried (Ahmann and Mathey, 1967).

\section{Preparation of the derivatives}

Compound 1 (200 mg) was treated with its corresponding alcohol $(50 \mathrm{~mL})$ and the mixture was refluxed for $20 \mathrm{~h}$ (Bachelor et al., 1979). After evaporation of the alcohol under reduced pressure, the reaction products were chromatographed using a silica gel column and eluted with chloroform to yield seven 2,4-dihydroxy-6-methyl benzoates (28 ), (yields 49.0 to $74.0 \%$ ). The structures were confirmed by spectroscopic methods (IR, ${ }^{1} \mathrm{H}$ (300 $\mathrm{MHz}),{ }^{13} \mathrm{C}$ (75 MHz) NMR, and MS) and compared with the literature data (Huneck and Yoshimura, 1996). 
<smiles>Cc1cc(OC(=O)c2c(C)cc(O)cc2O)cc(O)c1C(=O)O</smiles>

Lecanoric acid (1)<smiles>CCOC(=O)c1c(C)cc(O)cc1O</smiles>

ethyl orsellinate (3)<smiles>Cc1cc(O)cc(O)c1C(=O)OC(C)C</smiles>
iso-propyl orsellinate (5)<smiles>CCCCC(C)OC(=O)c1c(C)cc(O)cc1O</smiles>

s-butyl orsellinate (7)<smiles>COC(=O)c1c(C)cc(O)cc1O</smiles>

methyl orsellinate (2)<smiles>CCCOC(=O)c1c(C)cc(O)cc1O</smiles>

$n$-propyl orsellinate (4)<smiles>CCCCCCOC(=O)c1c(C)cc(O)cc1O</smiles>

n-butyl orsellinate (6)<smiles>Cc1cc(O)cc(O)c1C(=O)OC(C)(C)C</smiles>

t-butyl orsellinate (8)

Figure 1 - Structures of the compounds assayed.

\section{Bioassays}

Commercially available seeds of Lactuca sativa cv. Grand Rapids and Allium cepa cv. Baia Periforme were used. All undersized and damaged seeds were preselected for size uniformity. The germination and growth bioassays were conducted as follows: L. sativa, 50 seeds per dish, $1 \mathrm{~mL}$ test solution, Tween $80(100 \mu \mathrm{g} / \mathrm{mL}, 1.5 \mathrm{~mL})$, light, 25 ${ }^{\circ} \mathrm{C}$, in Petri dishes $(6 \mathrm{~cm})$ containing a $5.5 \mathrm{~cm}$ sheet of Whatman no. 1 filter paper disk, four replicates of each concentration; A. cepa, 50 seeds per dish,
$1.0 \mathrm{~mL}$ test solution, Tween $80(100 \mu \mathrm{g} / \mathrm{mL}, 1.5$ $\mathrm{mL}$ ), light, $15^{\circ} \mathrm{C}$, four replicates of each concentration (Brasil, 1992). The compounds were dissolved in acetone at $10^{-3} \mathrm{M}$ (stock solution) and those at $10^{-5}, 10^{-7}$, and $10^{-9} \mathrm{M}$ were obtained by dilution. The test solution was applied on the filter paper disk and then the solvent was evaporated. Studies with acetone and Tween 80 parallel controls were performed. To evaluate the seed emergence, readings were taken on a daily basis and after three days, the root and shoot lengths of 
germinated seeds were measured, in accordance with Leather and Einhellig (1986). The same procedure was applied to the controls.

\section{Statistical treatment}

The germination assay values were submitted to the Kruskal-Wallis multiple-comparison nonparametric test, since the data did not exhibit homogeneity of variance. Because the values obtained from the growth assays at the various concentrations met the assumptions of variance normality and homogeneity, they were submitted to ANOVA, in order to verify the occurrence of significant differences. To perform a multiplecomparison analysis of length mean values at the various concentrations in relation to controls, the Dunnett test was applied. For all statistical tests, a significance level of $\alpha=5 \%$ was adopted. Results are presented as percentage differences from control. Zero represents control, positive values represent stimulation, and negative values represent inhibition.

\section{RESULTS AND DISCUSSION}

Tables 1 and 2 and Fig. 2 show the results of the germination bioassays. Neither lecanoric acid nor its derivatives influenced the germination of $L$. sativa in a significant manner $(\mathrm{p}>0.05)$ at any of the concentrations tested. On the other hand, derivatives 3-6 significantly $(p>0.05)$ influenced the germination of $A$. cepa, though $s$-butyl orsellinate (7) had a significant action only at the highest concentration. Several reports are found in the literature on the germination- and growthregulating activity displayed by compounds isolated from lichens. The first attempt to determine the allelopathic potential of lichen compounds in lichen-lichen interactions made use of germination as an indicator of this potential (Lawrey, 1995).

Tables 1 and 2 and Fig. 2 also show the results of the radicle-growth bioassays. In $L$. sativa, radicle growth was significantly inhibited by orsellinates at most of the concentrations tested, with the exception of methyl orsellinate (2). In A. cepa, all the orsellinates significantly $(\mathrm{p}<0.05)$ inhibited radicle growth. In both the plant species, significant inhibition by lecanoric acid occurred at all three lower concentrations tested, but not at the highest one.

The growth of $L$. sativa hypocotyls (Table 1; Fig. 2) was significantly inhibited by lecanoric acid (1) at every concentration tested, but not by methyl (2) and $n$-butyl orsellinates (6). Ethyl (3) and $n$-propyl (4) orsellinates caused significant inhibition at the concentrations of $10^{-7} \mathrm{M}$ and $10^{-9} \mathrm{M}$, whereas isopropyl orsellinate (5) did so at $10^{-7} \mathrm{M}$ only and $s$ butyl (7) and $t$-butyl orsellinates (8) at $10^{-3} \mathrm{M}$ only. On the other hand, orsellinates 3-8 had a significant inhibiting action on A. cepa coleoptyls. Coleoptyl inhibition by methyl orsellinate (2) was significant, except at $10^{-5} \mathrm{M}$; inhibition by lecanoric acid (1) was significant, except at $10^{-3}$ M.

Table 1 - Germination and growth of seeds of Lactuca sativa treated with lecanoric acid (1) and seven of its derivatives (2-8), as compared with untreated controls.

\begin{tabular}{|c|c|c|c|c|c|c|c|c|c|c|c|c|c|c|c|}
\hline & \multicolumn{5}{|c|}{ Germination (\%; mean \pm SD) } & \multicolumn{5}{|c|}{ Root length (mm; mean \pm SD) } & \multicolumn{5}{|c|}{ Shoot length (mm; mean \pm SD) } \\
\hline & Contr. & $10^{-3} \mathrm{M}$ & $10^{-5} \mathrm{M}$ & $10^{-7} \mathrm{M}$ & $10^{-9} \mathrm{M}$ & Cont. & $10^{-3} \mathrm{M}$ & $10^{-5} \mathrm{M}$ & $10^{-7} \mathrm{M}$ & $10^{-9} \mathrm{M}$ & Contr. & $10^{-3} \mathrm{M}$ & $10^{-5} \mathrm{M}$ & $10^{-7} \mathrm{M}$ & I $10^{-9} \mathrm{M}$ \\
\hline 1 & & .50 & $\begin{array}{c}48.8^{\mathrm{ns}} \pm \\
1.26\end{array}$ & $\begin{array}{c}49.3^{\mathrm{ns}} \pm \\
0.96\end{array}$ & $\begin{array}{c}49.3^{\text {ns }} \pm \\
0.96\end{array}$ & $\begin{array}{r}29.6 \pm \\
0.22\end{array}$ & $\begin{array}{l}.1^{\mathrm{n}} \pm \\
.70\end{array}$ & $\begin{array}{c}28.3^{*} \pm \\
0.41\end{array}$ & $\begin{array}{c}26.4^{*} \pm \\
0.57\end{array}$ & $\begin{array}{c}25.4 * \pm \\
0.84\end{array}$ & & $\begin{array}{c}14.9 * \pm \\
0.77\end{array}$ & $\begin{array}{c}14.4^{*} \pm \\
0.39\end{array}$ & 0. & $\begin{array}{c} \pm 15,5^{*} \pm \\
0,49\end{array}$ \\
\hline 2 & $\begin{array}{r}50 \\
0 .\end{array}$ & $\begin{array}{c}48.5^{\mathrm{ns}} \pm \\
1.29\end{array}$ & $\begin{array}{c}49.3^{\mathrm{ns}} \pm \\
0.50\end{array}$ & $\begin{array}{c}49.3^{\mathrm{ns}} \pm \\
0.96\end{array}$ & $\begin{array}{c}49.8^{\mathrm{ns}} \pm \\
0.50\end{array}$ & $\begin{array}{r}30.8 \pm \\
2.24\end{array}$ & $\begin{array}{c}27.8^{\text {ns }} \pm \\
0.87\end{array}$ & $\begin{array}{c}26.6^{\mathrm{ns}} \pm \\
0.74\end{array}$ & $\begin{array}{c}28.0^{\mathrm{ns}} \pm \\
2.56\end{array}$ & $\begin{array}{c}27.1^{\mathrm{ns}} \pm \\
3.64\end{array}$ & $\begin{array}{c}17.3 \pm \\
1.00\end{array}$ & $\begin{array}{c}19.1^{\mathrm{ns}} \pm \\
0.38\end{array}$ & $\begin{array}{c}18.0^{\mathrm{ns}} \pm \\
0.68\end{array}$ & 1.1 & $\begin{array}{c} \pm 17,2^{\mathrm{ns}} \pm \\
2,10\end{array}$ \\
\hline 3 & $\begin{array}{l}0 \pm \\
00\end{array}$ & $\begin{array}{r}49.3 \\
0.9\end{array}$ & $\begin{array}{c}49.8^{\text {ns }} \pm \\
0.50\end{array}$ & $\begin{array}{c}49.5^{\mathrm{ns}} \pm \\
0.58\end{array}$ & $\begin{array}{c}49.3^{\text {ns }} \pm \\
0.96\end{array}$ & $\begin{array}{r}30.8 \pm \\
2.24\end{array}$ & $\begin{array}{c}23.9^{*} \pm \\
3.13\end{array}$ & $\begin{array}{c}23.7 * \pm \\
3.14\end{array}$ & $\begin{array}{c}23.7 * \pm \\
1.09\end{array}$ & $\begin{array}{c}23.3^{*} \pm \\
0.54\end{array}$ & $\begin{array}{c}17.3 \pm \\
1.00\end{array}$ & $\begin{array}{c}16.0^{\mathrm{ns}} \pm \\
1.37\end{array}$ & $\begin{array}{c}16.0^{\mathrm{ns}} \pm \\
1.21\end{array}$ & $0.77^{-1}$ & $\begin{array}{c}15,0^{*} \pm \\
0,60\end{array}$ \\
\hline 4 & $\begin{array}{c}50.0 \pm \\
0.00\end{array}$ & $\begin{array}{r}50.0 \\
0.0\end{array}$ & $\begin{array}{c}50.0^{\mathrm{ns}} \pm \\
0.00\end{array}$ & $\begin{array}{c}50.0^{\mathrm{ns}} \pm \\
0.00\end{array}$ & $\begin{array}{c}50.0^{\mathrm{ns}} \pm \\
0.00\end{array}$ & $\begin{array}{r}30.8 \pm \\
2.24\end{array}$ & $\begin{array}{c}23.5^{*} \pm \\
2.17\end{array}$ & $\begin{array}{c}23.3^{*} \pm \\
1.26\end{array}$ & $\begin{array}{c}23.6^{*} \pm \\
0.92\end{array}$ & $\begin{array}{c}23.6^{*} \pm \\
1.28\end{array}$ & $\begin{array}{c}17.3 \pm \\
1.00\end{array}$ & $\begin{array}{c}16.2^{\mathrm{ns}} \pm \\
0.52\end{array}$ & $\begin{array}{c}16.7^{\mathrm{ns}} \pm \\
0.34\end{array}$ & $\begin{array}{c}15.7 * \pm \\
0.62\end{array}$ & $\begin{array}{c}15,4^{*} \pm \\
0,51\end{array}$ \\
\hline 5 & $\begin{array}{r}50.0 \\
0.0\end{array}$ & $\begin{array}{r}49.0 \\
1 .\end{array}$ & $\begin{array}{c}50.0^{\mathrm{ns}} \pm \\
0.00\end{array}$ & $\begin{array}{c}49.5^{\mathrm{ns}} \pm \\
1.00\end{array}$ & $\begin{array}{c}49.5^{\mathrm{ns}} \pm \\
0.58\end{array}$ & $\begin{array}{r}30.8 \pm \\
2.24\end{array}$ & $\begin{array}{c}23.5^{*} \pm \\
2.59\end{array}$ & $\begin{array}{c}26.4^{\mathrm{ns}} \pm \\
1.75\end{array}$ & $\begin{array}{c}22.8 * \pm \\
0.96\end{array}$ & $\begin{array}{c}27.5^{\mathrm{ns}} \pm \\
2.89\end{array}$ & $\begin{array}{c}17.3 \pm \\
1.00\end{array}$ & $\begin{array}{c}15.8^{\mathrm{ns}} \pm \\
0.91\end{array}$ & $\begin{array}{c}17.1^{\mathrm{ns}} \pm \\
1.16\end{array}$ & $\begin{array}{c}15.4^{*} \\
0.72\end{array}$ & $\begin{array}{c} \pm 17,4^{\mathrm{ns}} \pm \\
0,35\end{array}$ \\
\hline 6 & $\begin{array}{c}50.0 \pm \\
0.00\end{array}$ & $\begin{array}{r}49.3 \\
0.9\end{array}$ & $\begin{array}{c}49.5^{\mathrm{ns}} \pm \\
0.58\end{array}$ & $\begin{array}{c}50.0^{\mathrm{ns}} \pm \\
0.00\end{array}$ & $\begin{array}{r}49.5^{\mathrm{n}} \\
1.0\end{array}$ & $\begin{array}{r}30.8 \pm \\
2.24\end{array}$ & $\begin{array}{c}28.0^{\mathrm{ns}} \pm \\
1.99\end{array}$ & $\begin{array}{c}27.6^{\mathrm{ns}} \pm \\
2.74\end{array}$ & $\begin{array}{c}24.9 * \pm \\
1.26\end{array}$ & $\begin{array}{c}23.8^{*} \pm \\
0.94\end{array}$ & $\begin{array}{c}17.3 \pm \\
1.00\end{array}$ & $\begin{array}{c}18.0^{\mathrm{ns}} \pm \\
1.25\end{array}$ & $\begin{array}{c}17.3^{\mathrm{ns}} \pm \\
1.32\end{array}$ & $\begin{array}{r}16.5 \\
0 .\end{array}$ & $\pm \underset{1,17}{16,3^{\mathrm{ns}} \pm}$ \\
\hline 7 & $\begin{array}{c}50.0 \pm \\
0.00\end{array}$ & $\begin{array}{c}49.3^{\mathrm{ns}} \pm \\
0.96\end{array}$ & $\begin{array}{c}49.5^{\mathrm{ns}} \pm \\
0.58\end{array}$ & $\begin{array}{c}49.3^{\mathrm{ns}} \pm \\
0.96\end{array}$ & $\begin{array}{c}49.8^{\mathrm{ns}} \pm \\
0.50\end{array}$ & $\begin{array}{r}30.8 \pm \\
2.24\end{array}$ & $\begin{array}{c}23.2 * \pm \\
1.44\end{array}$ & $\begin{array}{c}24.6^{*} \pm \\
2.26\end{array}$ & $\begin{array}{c}25.1 * \pm \\
2.35\end{array}$ & $\begin{array}{c}24.4^{*} \pm \\
1.35\end{array}$ & $\begin{array}{c}17.3 \pm \\
1.00\end{array}$ & $\begin{array}{c}14.6^{*} \pm \\
0.26\end{array}$ & $\begin{array}{c}18.4^{\mathrm{ns}} \pm \\
1.51\end{array}$ & $\begin{array}{r}16.4 \\
0.8\end{array}$ & $\begin{array}{c} \pm 17,2^{\mathrm{ns}} \pm \\
1,21\end{array}$ \\
\hline 8 & $\begin{array}{c}50.0 \pm \\
0.00\end{array}$ & $\begin{array}{c}49.5^{\mathrm{ns}} \pm \\
1.00\end{array}$ & $\begin{array}{c}49.5^{\mathrm{ns}} \pm \\
0.58\end{array}$ & $\begin{array}{c}50.0^{\mathrm{ns}} \pm \\
0.00\end{array}$ & $\begin{array}{c}49.8^{\mathrm{ns}} \pm \\
0.50\end{array}$ & $\begin{array}{r}30.8 \pm \\
2.24\end{array}$ & $\begin{array}{c}23.1 * \pm \\
0.56\end{array}$ & $\begin{array}{c}23.6^{*} \pm \\
0.75\end{array}$ & $\begin{array}{c}23.9 * \pm \\
1.42\end{array}$ & $\begin{array}{c}24.3 * \pm \\
2.05\end{array}$ & $\begin{array}{c}17.3 \pm \\
1.00\end{array}$ & $\begin{array}{c}15.6^{*} \pm \\
0.76\end{array}$ & $\begin{array}{c}16.5^{\mathrm{ns}} \pm \\
0.71\end{array}$ & $\begin{array}{c}16.0^{\mathrm{ns}} \pm \\
0.49\end{array}$ & $\begin{array}{c} \pm 16,9^{\mathrm{ns}} \pm \\
0,38\end{array}$ \\
\hline
\end{tabular}

${ }^{\mathrm{ns}}$ Mean values not significantly different from controls; ${ }^{*}$ Mean values significantly different from controls. 
Lactuca sativa
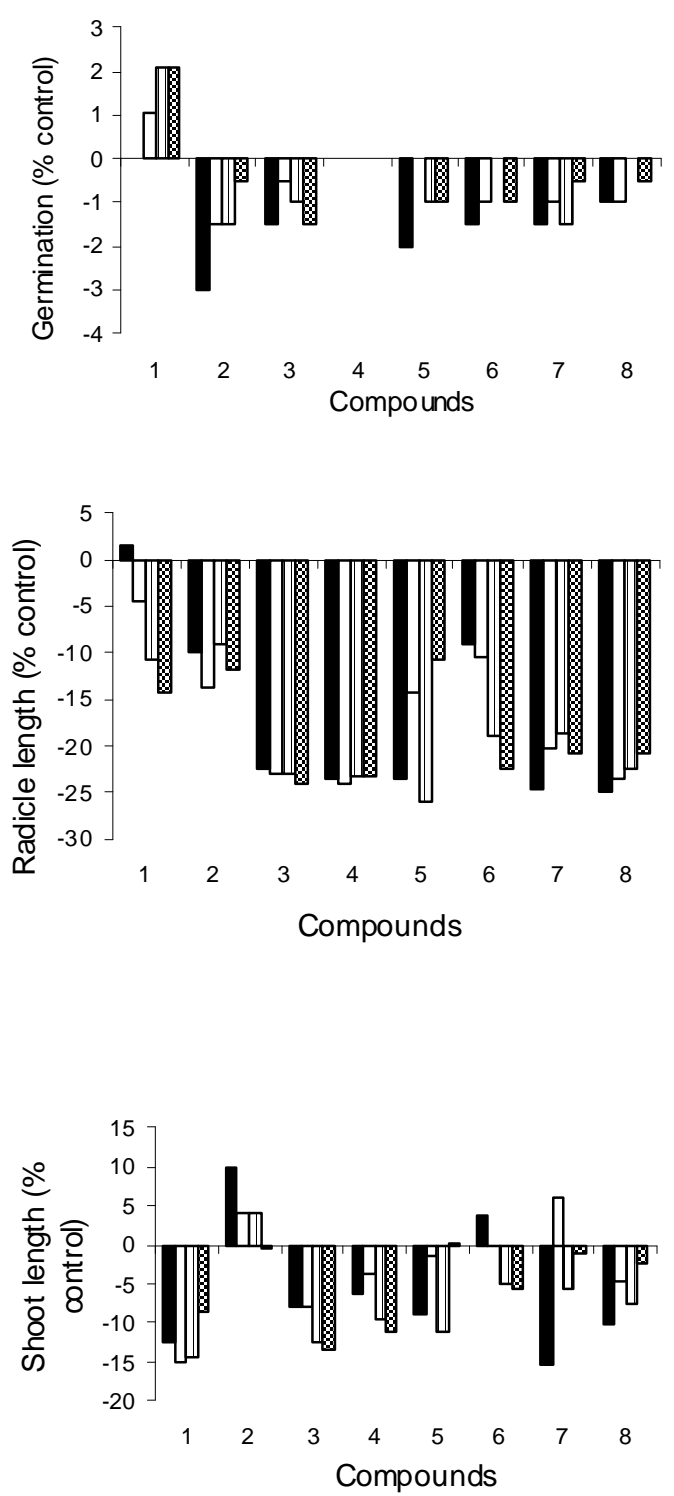

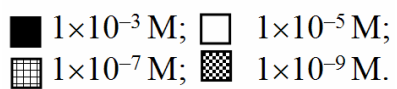

Allium cepa
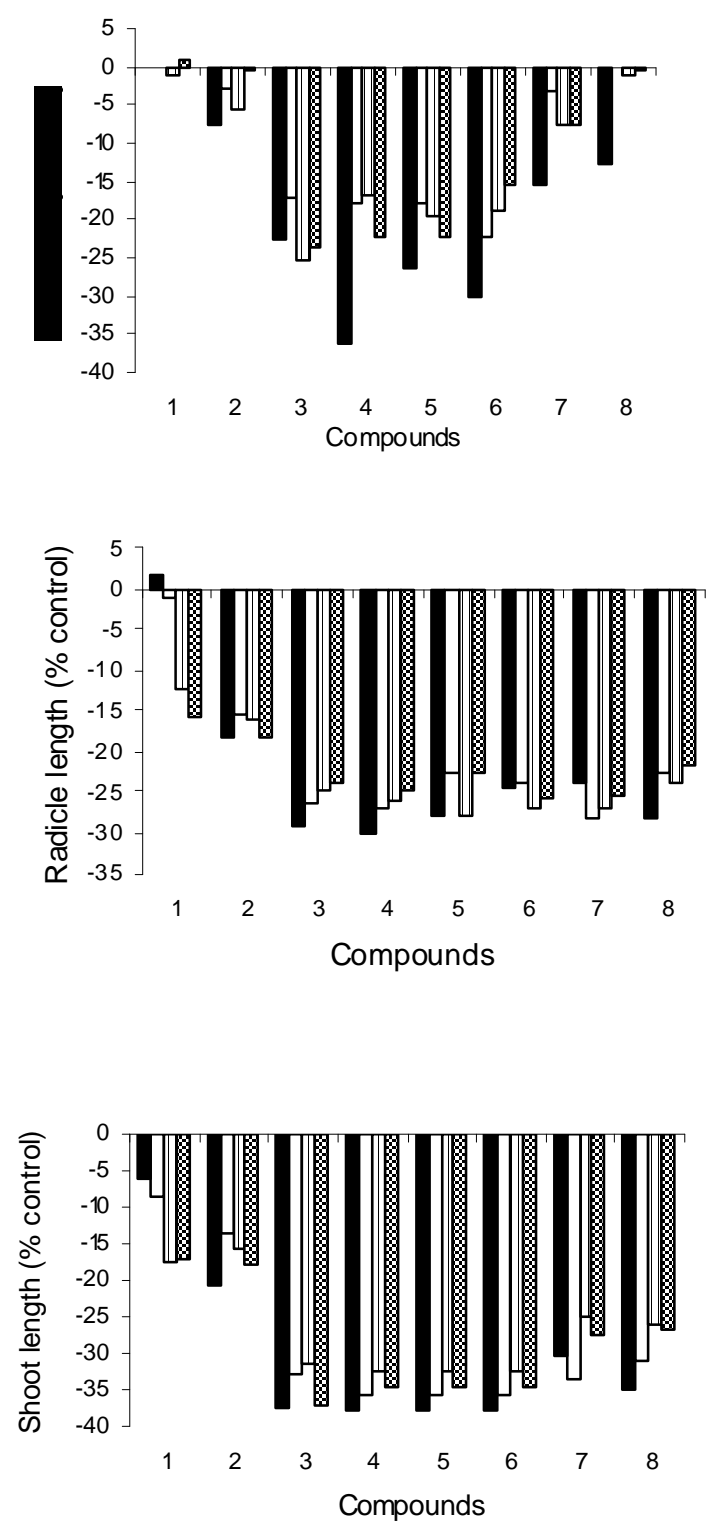

Figure 2 - Effect of compounds 1-8 on germination and seedling growth of Lactuca sativa (left) and Allium cepa (right). 
Table 2 - Germination and growth of seeds of Allium cepa treated with lecanoric acid (1) and seven of its derivatives (2-8), as compared with untreated controls.

\begin{tabular}{|c|c|c|c|c|c|c|c|c|c|c|c|c|c|c|c|}
\hline & \multicolumn{5}{|c|}{ Germination (\%; mean \pm SD) } & \multicolumn{5}{|c|}{ Root length (mm; mean \pm SD) } & \multicolumn{5}{|c|}{ Shoot length $(\mathrm{mm} ;$ mean \pm SD) } \\
\hline & Cont. & $10^{-3} \mathrm{M}$ & $10^{-5} \mathrm{M}$ & $10^{-7} \mathrm{M}$ & $10^{-9} \mathrm{M}$ & Contr. & $10^{-3} \mathrm{M}$ & $10^{-5} \mathrm{M}$ & $10^{-7} M$ & $10^{-9} \mathrm{M}$ & Contr. & $10^{-3} \mathrm{M}$ & $10^{-5} \mathrm{M}$ & $10^{-7} \mathrm{M}$ & $10^{-9} \mathrm{M}$ \\
\hline \multirow[t]{2}{*}{1} & 48.0 & $48.0^{\mathrm{n}}$ & $48.0^{\mathrm{ns}}$ & $47.5^{\mathrm{ns}}$ & $48.5^{\mathrm{ns}}$ & 8.5 & $8.6^{*}$ & $8.4^{*}$ & $7.4^{*}$ & $7.1 *$ & 10.9 & $10.3^{\mathrm{ns}}$ & $10.0^{*}$ & $9.0^{*}$ & $9.0^{*}$ \\
\hline & \pm 0.96 & \pm 0.8 & \pm 0.00 & \pm 0.85 & \pm 0 . & \pm 0.38 & & & & \pm 0.50 & \pm 0.39 & & \pm 0.22 & \pm 0.48 & \pm 0.55 \\
\hline \multirow[t]{2}{*}{2} & 5.0 & & & & 44. & 8.7 & & & & 7.1 & 12.4 & & & $0.4 *$ & $10.2 * \pm$ \\
\hline & \pm 1.41 & & \pm 2 & & \pm 0 . & \pm 0.71 & 9 & \pm 0.87 & & \pm 0.4 & 1.36 & & & .46 & \\
\hline \multirow[t]{2}{*}{3} & 46.3 & & & & & 8.7 & & & & & 12.4 & & & $3.5 *$ & $7.8 *$ \\
\hline & \pm 0.50 & \pm 2.63 & \pm 1.89 & \pm 2 & \pm 2 . & \pm 0.71 & \pm 0.44 & \pm 0.17 & & & \pm 1.36 & & & & \pm 0.71 \\
\hline \multirow[t]{2}{*}{4} & 45.0 & & & & & 8.7 & & $6.3^{*}$ & $6.4^{*}$ & $6.5^{*}$ & 12.4 & & & $8.4 *$ & $8.1 *$ \\
\hline & \pm 1.41 & & \pm 2 & & & 0.71 & & & & & & & & & \\
\hline \multirow[t]{2}{*}{5} & 46.3 & & & & & 8.7 & & & & & 12 & & & 4* & $8.1^{*}$ \\
\hline & \pm 0.50 & \pm 4 & \pm 3 & & \pm 4 & \pm 0.71 & \pm 0.41 & \pm 0.27 & \pm 0.24 & \pm 0.26 & \pm 1.36 & & & & \pm 0.17 \\
\hline \multirow[t]{2}{*}{6} & 45.0 & & $35.0 *$ & & & 8.7 & $6.6^{*}$ & $6.6^{*}$ & $6.3^{*}$ & $6.4 *$ & 12.4 & $7.7 *$ & $8.0^{*}$ & $8.4 *$ & $8.1^{*}$ \\
\hline & \pm 1.41 & \pm 2.38 & \pm 2.94 & \pm 1 & \pm 1 & \pm 0.71 & \pm 0.21 & \pm 0.14 & \pm 0.21 & \pm 0.13 & \pm 1.36 & & & \pm 0.43 & \pm 0.55 \\
\hline \multirow[t]{2}{*}{7} & 45.0 & & $43.5^{\mathrm{s}} \pm$ & & & 8.7 & & & & & 12 & & & 3* & $9.0 *$ \\
\hline & \pm 1.41 & \pm 1 & & & \pm 5 & \pm 0.71 & & \pm 0.3 & & \pm 0 & \pm 1 . & & & & \pm 0.33 \\
\hline \multirow[t]{2}{*}{8} & 45.0 & & $45.0^{\mathrm{ns}}$ & $44.5^{\mathrm{ns}}$ & 44.8 & 8.7 & $6.2 *$ & 6.7 & 6.6 & $6.8^{\circ}$ & 12.4 & $8.0 *$ & & $9.2 *$ & $9.1 *$ \\
\hline & \pm 1.41 & \pm 4.03 & \pm 3.65 & \pm 4.12 & \pm 0.50 & \pm 0.71 & \pm 0.38 & \pm 0.66 & \pm 0.29 & \pm 0.37 & \pm 1.36 & \pm 0.62 & \pm 0.33 & \pm 0.51 & \pm 0.40 \\
\hline
\end{tabular}

${ }^{\overline{n s}}$ Mean values not significantly different from controls; ${ }^{*}$ Mean values significantly different from controls.

Similar results were observed by Macías et al. (1996) in bioassays with sesquiterpene lactones that inhibited $L$. sativa radicles and hypocotyls at the lower concentrations tested. With allelochemicals, significant activities might not occur at higher concentrations (Macías et al., 2000). This was also observed in assays with several concentrations of D-usnic acid and Pisolithus tinctorius: fungus inhibition required the $10-$ to $50-\mathrm{mg} / \mathrm{L}$ series of the acid, whereas no significant differences in growth were observed at $100 \mathrm{mg} / \mathrm{L}$ (Goldner et al., 1986).

Although lichens are capable of inhibiting both the germination and growth of certain organisms, the particular combination of species and inhibiting concentrations may be rather well-defined (Kershaw, 1985 in Lawrey, (1995); Lawrey, 1984 in Lawrey, (1995). Field observations have revealed that crustose lichens inhibit the growth in bryophytes and vascular epiphytes. Experiments for investigating the action of extracts of the lichens Cryptotheca sp. and Pertusaria sp. on the germination of the mosses Ceratodon purpureus and Funaria hygrometrica and of seeds of Vriesea splendens (Bromeliaceae) and Lepidium sativum (Brassicaceae) showed that the extracts were capable of inhibiting the germination both of spores and seeds (Frahm et al., 2000).

In the present investigation, the effects of lecanoric acid (1) and orsellinates (2-8) on the germination of L. sativa and A. cepa were less pronounced than those on the growth of radicles and hypocotyls/coleoptyls of these species, which corroborate the results obtained by Wardle et al.
(1992). According to Ferreira and Áquila (2000), radicle elongation is a much more sensitive indicator of potentially allelopathic agents than seed germination is.

The chemical structure of the compounds evaluated does play a role in their activity (Nishitoba and Nishimura, 1987). In fact, an increase in the number of carbon atoms in the ester chain of orsellinates 3-8 was reflected in improved activity. However, in assays of methyl orsellinate (2) on Amaranthus hypochondriacus (Amaranthaceae) and Echinochloa crusgalli (Poaceae), significant inhibition was observed both in germination and radicle growth (Rojas et al., 2000).

Some indirect evidence suggest that the chemical nature of secondary metabolites correlates with the competitive ability of lichens (Rogers, 2000).

The results of the present potential allelopathic activity bioassays showed that lecanoric acid (1) and its seven derivatives investigated (2-8) did not influenced the germination of $L$. sativa in a significant manner (Table 1, Fig. 2), although orsellinates 3-6 significantly influence the germination of A. cepa (Table 2, Fig. 2). Also, A. cepa more sensitive to the compounds assayed, at any of the four concentrations tested. Nearly all the esters evaluated exhibited significant effects, a feature that could make them potentially promising for the development of new natural herbicides.

Although the present experiments did not elucidate the model of action of lecanoric acid and orsellinates, it was evident that these molecules 
have potential allelopathic features and that the germination and growth responses were particular to each species, hence their high variability. The results achieved in this investigation and the success of the method adopted provided encouragement for surveying new compounds with phytotoxic activity.

\section{ACKNOWLEDGMENTS}

The authors thank Dr. Mariana Fleig for identifying the lichen species, CNPq and PROPP/UFMS

\section{RESUMO}

A degradação do meio ambiente ocasionada pelo uso excessivo de agrotóxicos impulsiona pesquisas que visam a descoberta de novos pesticidas. Os bioensaios conduzidos em condições de laboratório no presente estudo, envolveu a germinação e o crescimento de plântulas de Lactuca sativa cv. Grand Rapids e Allium cepa cv. Baia Periforme tratadas com ácidos lecanórico ou um dos sete ésteres obtidos pela alcoólise deste ácido. Cada substância foi ensaiada nas concentrações $10^{-3} \mathrm{M}, 10^{-5} \mathrm{M}, 10^{-7} \mathrm{M}$, e $10^{-9} \mathrm{M}$. Os resultados indicaram que exceto o ácido lecanórico e o orselinato de metila, todos os demais apresentaram diferenças significativas em relação ao controle. Além disso, observou-se que A. серa foi mais sensível aos compostos ensaiados, nas quatro concentrações. Praticamente todos os ésteres avaliados apresentaram efeitos significativos, o que os torna compostos potenciais na descoberta de novos herbicidas naturais.

\section{REFERENCES}

Ahmann, G. B.; Mathey A. (1967), Lecanoric acid and some constituents of Parmelia tinctorum and Pseudevernia intensa. The Bryologist, 20, 93-97.

Bachelor, F. W.; Cheriyan, U. O.; Wong J. D. (1979), Cleavage of depsides by tert-butyl alcohol. Phytochem., 18, 487-488.

Brasil. Ministério da agricultura. (1992), Regras para a análise de sementes, 365pp.

Cobb, A. (1992), Herbicides and plant physiology, Chapmam and Hall: London, p. 176.

Duke, S. O.; Abbas, H. K. (1995), Natural products with potential use as herbicides, In Allelopathy Organisms, Processes and Applications, Inderjit; Dakshini, K. M. M.; Einhellig, F. A. Eds.; ACS Symposium, Series 582: Washington, DC, USA, pp. 348-362.

Einhellig, F. A. (1995), Allelopathy: Current status and future goals. In: Allelopathy: Organisms, Processes and Applications, Inderjit, Dakshini, K.M.M. and Einhellig, F.A, Eds.; Am. Chem. Soc. Washington DC, USA, pp. 01-24

Ferreira, A. G.; Aquila, M. E. A. (2000), Alelopatia: uma área emergente da ecofisiologia. Rev. Bras. Fisiol. Veg., 12, 175-204.

Frahm, J. P.; Specht, A.; Reifenrath, K.; Vargas, Y. L. (2000), Allelopathic effects of crustose lichens, epiphytic bryophytes and vascular plants. Nova Edwigia, 70, 1-2.

Goldner, W. R.; Hoffman, F. M.; Medve, R. J. (1986), Allelopathic effects of Cladonia cristatella on ectomycorrhizal fungi common to bituminous strip mine spoils. Can. J. Bot., 64, 1586-1590.

Gomes, A. T.; Honda, N. K.; Roese, F. M.; Muzzi, R. M.; Marques, M. R. (2002), Bioactive derivatives obtained from lecanoric acid, a constituent of the lichen Parmotrema tinctorum (Nyl.) Hale (Parmeliaceae). Rev. Brasil. de Farmac., 12 (supl.), 74-75.

Gomes, A T.; Smania, Jr. A.; Seidel, C.; Smania, E. F. A.; Honda, N. K.; Rose, F. M.; Muzzi, R. M. (2003), Antibacterial activity of orsellinates. Braz. J. Microbiol., 34, 194-196.

Huneck, S.; Yoshimura, I. (1996). Identification of lichen substances. Springer-Verlag, Berlin, pp. 403446. 
Lawrey, J. D. (1995), Lichen Allelopathy: A Review. In Allelopathy: organisms, processes and applications, Inderjit, Dakshini, K.M.M. and Einhellig, F.A, Eds.; Am. Chem. Soc.: Washington, DC, USA, pp. 26-38.

Leather, G. R.; Einhellig, F. A. (1986), Bioassays in the study of allelopathy. In The Science of Allelopathy; Putnam, A. R; Tang, C.S., Eds.; A. WileyInterscience Publication U.S.A, pp. 133-145.

Macías, F. A.; Torres, A.; Molinillo, J. M. G.; Varela, R.M.; Castellano, D. (1996), Potential allelopathic sesquiterpene lactones from sunflower leaves. Phytochem., 43, 1205-1215.

Macías, F. A.; Castellano, D.; Molinillo, M. G. (2000), Search for a standard phytotoxic bioassay for allelochemicals: selection of standard target species. J. Agric. Food Chem., 48, 2512-2521.

Marante, F. J. T.; Castellano, A. G.; Rosas, F. E.; Aguiar, Q.; Barrera, J. B. (2003), Identification and quantification of allelochemicals from the lichen Lethariella canariensis: Phytotoxicity and antioxidative activity. J. Chem. Ecol., 29, 2049-2071.

Nishitoba, Y.; Nishimura, H. et al. (1987), Lichen acids, plant growth inhibitors from Usnea longissima. Phytochem., 26, 3181-3185.
Peres, M.T.L.P.; Pizzolatti, M.G.; Queiroz, M.H.; Yunes, R.A. (1998), Potencial de atividade alelopática de Gleichenia pectinata Willd (PR). Pesq. Agropec. Bras., 33, 131-137.

Rojas, I. S.; Lotina-Hennsen, B.; Mata, R. (2000), Effect of lichen metabolites on thylakoid electron transport and photophosphorylation in isolated spinach chloroplasts. J. Nat. Prod., 63, 1396-1399.

Rogers, A. (1999), Ecological strategies in lichens. Lichenologist, 22, 149-162.

Silva Cruz, M. E.; Nozaki, M. H.; Batista, M. A. (2000), Plantas medicinais e alelopatia. Biotecnologia - Ciência e desenvolvimento. <Available from: http://biotecnologia.uol.com.br/revista/bio15/15_e.as p> Access: 11 May 2004.

Wardle, D. A.; Nicholson, K. S.; Almed, M. (1992), Comparison of osmotic and allelopathic effects of grass leaf extracts on radicle elongation. Plant Soil, 140, 315-319.
Received: October 09, 2006; Revised: July 12, 2007; Accepted: November 14, 2008 